\title{
PENERAPAN MODEL PEMBELAJARAN KOOPERATIF JIGSAW UNTUK MENINGKATKAN MOTIVASI PADA SISWA KELAS V SEKOLAH DASAR
}

\author{
${ }^{1}$ Bandi Usman, ${ }^{2}$ Khairil Akbar, ${ }^{3}$ Kurnia Dyah A, M.Or. \\ ${ }^{1}$ Mahasiswa Penjaskesrek STKIP Melawi \\ ${ }^{2,3}$ Dosen Penjaskesrek STKIP Melawi \\ Jl. RSUD Melawi km.04. Kec. Nanga Pinoh, Kab. Melawi Kalimantan Barat \\ Email: usmanbandi@yahoo.com \\ khairilakbar89@gmail.com, kurniastkipmelawi@gmail.com
}

\begin{abstract}
Abstrak: This study aims to increase student learning motivation in the field of physical education, sports and health. The learning model used is the application of the learning model through cooperative jigsaw to increase learning motivation in the field of physical education, sports and healthfor fifth grade students. Classroom action research (PTK) is carriedout using data collection techniques, namely motivation tests and questionnaires. The results of this study showed that in cycle 1, the average value of student learning motivation was $73 \%$ in the motivated category but not yet complete. Then in cycle II obtained a percentage of learning motivation of $90 \%$ categorized as motivated according to the success criteria and seen from the point of view of the maximum completeness criteria (KKM) students are said to be complete. The percentage of increasing learning motivation from cycle I to cycle II was 17\%. The jigsaw cooperative learning model can increase student motivation, especially in sports and health physical education subjects.
\end{abstract}

Keywords: learning Model, motivation to learn physical education sports and health.

Abstrak: Penelitian ini bertujuan untuk meningkatkan motivasi belajar siswa pada bidang studi Pendidikan Jasmani Olahraga dan Kesehatan. Model pembelajaran yang digunakan adalah penerapan model pembelajaran melalui kooperatif Jigsaw untuk meningkatkan motivasi belajar pada bidang studi Pendidikan Jasmani Olahraga dan Kesehatan pada siswa kelas V, dilakukan penelitian tindakan kelas (PTK) dengan teknik pengumpulan data yakni tes dan angket motivasi. Hasil penelitian ini diperoleh siklus I nilai rata-rata motivasi belajar siswa presentase sebesar 73\% kategori termotivasi tetapi belum tuntas. Kemudian pada siklus II diperoleh presentase motivasi belajar sebesar 90\% dikategorikan termotivasi sesuai kriteria keberhasilan dan dilihat dari sudut pandang kriteria ketuntasan maksimal (KKM) siswa sudah dikatakan tuntas. Presentase peningkatan motivasi belajar siklus I ke siklus II yaitu $17 \%$. Model pembelajaran kooperatif jigsaw dapat meningkatkan motivasi belajar siswa, terutama pada mata pelajaran Pendidikan Jasmani Olahraga dan Kesehatan.

Kata Kunci: Model Pembelajaran, Motivasi Belajar Pendidikan Jasmani Olahraga dan Kesehatan 
$\mathrm{P}$ endidikan Jasmani, Olahraga, dan Kesehatan adalah mata pelajaran yang membekali siswa dalam pengetahuan dan kemampuan dalam melakukan gerak jasmani dalam berolahraga dan menjaga kesehatannya, serta sikap prilaku yang dituntut dalam berolahraga dan menjaga kesehatan sebagai suatu kesatuan utuh, sehingga terbentuk peserta didik yang sadar kebugaran jasmani, sadar olahraga dan sadar kesehatan serta tidak terlepas sadar akan bagaimana pentingnya nilai-nilai yang ada di dalamnya.

Dari hasil pengamatan yang dilakukan, maka dapat di simpulkan bahwa pada pelajaran khususnya pelajaran Pendidikan Jasmani, Olahraga dan Kesehatan (PJOK), peneliti melihat hasil belajar di bawah KKM. Oleh karena itu peneliti menggunakan pendekatan pembelajaran model kooperatif jigsaw yang disesuaikan dengan kurikulum pembelajaran yang ada di Sekolah Dasar, guna untuk membuktikan bahwa penggunaan Model Pembelajaran Kooperatif Jigsaw dapat meningkatkan motivasi belajar.

Pembelajaran kooperatif adalah strategi pembelajaran yang melibatkan partisipasi siswa dalam satu kelompok kecil untuk saling berinteraksi menurut Nurulhayati dalam Rusman (2009:197). Dalam sistem belajar yang kooperatif, siswa belajar bekerja sama bersama anggota lainnya. Dalam model ini siswa memiliki dua tanggung jawab, yaitu mereka belajar untuk dirinya sendiri dan membantu sesama anggota kelompok untuk belajar. Siswa belajar bersama - sama dalam sebuah kelompok kecil dan mereka dapat melakukannya seorang diri. Terdapat empat hal penting dalam strategi pembelajaran kooperatif, yakni : (1) adanya peserta didik dalam kelompok ; (2) adanya aturan main (role) dalam kelompok; (3) adanya upaya belajar dalam kelompok; (4) adanya kompetensi yang harus dicapai oleh kelompok. Berkenaan dengan pengelompokan siswa dapat ditentukan berdasarkan atas: (1) minat dan bakat siswa; (2) latar belakang kemampuan siswa; perpaduan antara minat \& bakat siswa dan latar kemampuan siswa.

Dalam model koomperatif jigsaw kegiatan yang dilakukan oleh siswa adalah sebagai berikut: a. Melakukan membaca untuk mengali informasi. Siswa memperoleh topik-topik permasalah untuk dibaca sehingga mendapatkan informasi dari permasalahan tersebut. b. Diskusi kelompok ahli. Siswa yang telah mendapatkan topik permasalahan yang sama bertemu dalam suatu kelompok untuk membicarakan topik permasalahn tersebut. c. Laporan kelompok. Kelompok ahli kembali ke kelompok asal dan menjelaskan hasil yang didapat dari diskusi tim ahli. d. Kuis dilakukan mencakup semua topik permasalah yang 
dibicarakan tadi. Perhitungan skor kelompok dan menentukan perhargaan kelompok.

Stephen, Sikes and Snapp (1978:204) mengemukan langkah-langkah pembelajarn kooperatif jigsaw sebagai berikut: (1) Siswa dikelompokkan ke dalam 1 sampai 5 anggota tim. (2) Tiap orang dalam tim diberi bagian materi yang berbeda. (3) Tiap orang dalam tim diberi bagian materi yang ditugaskan. (4) Anggota dari tim kelompok baru (kelompok ahli) untuk mediskusikan subbab mereka. (5) Tiap tim ahli memprestasikan hasil diskusi. (6) Guru memberikan evaluasi. (7) Penutup.

\section{METODOLOGI PENELITIAN}

Prosedur penalitian menggunakan penelitian tindakan kelas yang dipilih adalah model (PTK) yang dikembangkan dari Kurt Lewin (Sangadji \& Sopiah 2010:112). Konsep pokok penelitian tindakan model Kurt Lewin terdiri dari empat tahap, yaitu perencanaan, tindakan, observasi dan refleksi. Penelitian ini direncanakan beberapa siklus, masing-masing siklus ada empat tahap kegiatan. Dalam rancangan penelitian ini terdapat beberapa siklus yang akan dilakukan untuk memperbaiki setiap proses pembelajaran dan melihat ada tidaknya motivasi belajar siswa dengan menerapkan model kooperatif jigsaw dalam pembelajaran.

Subjek dalam penelitian ini adalah adalah siswa kelas V SD Sungai Kehidupan yang berjumlah 24 orang. Dengan jumlah siswa laki-laki 9 orang dan siswa perempuan 15 orang. Objek penelitian adalah motivasi belajar dan penerapan pembelajaran kooperatif model jigsaw. Observasi adalah cara menghimpun bahan-bahan keterangan data yang dilakukan dengan mengadakan pengatan dan pencatatan secara sistematis terhadap fenomena-fenomena yang sedang dijadikan secara pengamatan. Observasi sebagai alat evaluasi banyak di gunakan untuk menilai tingkah laku individu atau proses terjadinya suatu kegiatan yang diamati, baik dalam situasi yang sebenarnya maupun dalam situasi bantuan.

Teknik pengumpulan data dilakukan untuk memperoleh informasi yang dibutuhkan dalam rangka mencapai tujuan penelitian (Gulo. 2002: 110). Pengamatan langsung dilakukan pada proses pembelajaran, dengan teknik pengumpulan data yang digunakan oleh peneliti yaitu angket dan tes tertulis. Lembar instrumen angket penilaian diri sikap peserta didik terhadap pembelajaran Pendidikan Jasmani, Olahraga, dan Kesehatan. Angket penilaian menggunakan tanggapan Ya atau Tidak dengan 25 butir pernyataan. Keterangan pengisian angket, yaitu: a. Apabila peserta didik menjawab ya pada pernyataan positif diberi skor satu (1), sebaliknya jika menjawab tidak pada pernyataan negatif diberi skor nol (0). b. Apabila peserta didik menjawab ya pada pernyataan negatif diberi 
skor nol (0), sebaliknya jika menjawab tidak pada pernyataan positif diberi skor satu (1).

Analisis data dilakukan setelah siklus selesai dilaksanakan, dengan melihat hasil tes setiap siklus, melalui gambar, dan lembar observasi. Data dianalisis berdasarkan hasil tes tertulis sebagai indikator utama dalam menarik kesimpulan peningkatan hasil belajar yang berarti adanya peningkatan aktivitas belajar pada siswa. Hasil analisis tahap pertama, yang berasal dari lembar observasi, dan hasil tes digunakan sebagai acuan untuk menentukan tahap penelitian selanjutnya.

Penskoran dilakukan sebagai berikut:

Nilai $=\frac{\text { Nilai Perolehan }}{\text { Nilai Maksimal }} \times 100$

Tingkat keberhasilan adalah standar yang sudah di tentukan atau digunakan untuk menentukan hasil atau tidaknya sesuatu penelitian. Dari hasil penilaian masing-masing sesuai dengan patokan nilai dengan perhitungan perolehan skor. Keberhasilan dalam penelitian ini dengan persentase $75 \%$, yang akan dipapar tabel di bawah ini:

Tabel 3.3. Kriteria Keberhasilan

\begin{tabular}{|c|c|}
\hline $\begin{array}{c}\text { Interval } \\
\text { (rentangan) }\end{array}$ & Kategori \\
\hline $91-100 \%$ & Sangat Termotivasi \\
\hline $71-90 \%$ & Termotivasi \\
\hline $61-70 \%$ & Mulai Termotivasi \\
\hline$\leq 61 \%$ & Kurang Termotivasi \\
\hline
\end{tabular}

Komarudin (2016:56-57)
Sebagai kriteria keberhasilan, peneliti menetapkan nilai rata-rata minimal 75, sesuai kriteria ketuntasan minimal (KKM) adalah $70 \%$ yang ditetapkan oleh Sekolah Dasar Sungai Kehidupan.

\section{HASIL PENELITIAN DAN PEMBAHASAN}

Deskripsi hasil tindakan tiap siklus yang penelitian ini dilakukan dalam dua siklus yang masing-masing siklus terdiri dari empat tahapan yaitu: (1) tahap perencanaan tindakan, (2) tahap pelaksanaan tindakan, (3) tahap observasi dan evaluasi, (4) tahap analisis dan refleksi. Dalam tahap pelaksanaan tindakan ada 3 pertemuan. pertemuan pertama pada hari Selasa, 19 November 2019 pukul 08.00-09.00 di kelas V Sekolah Dasar Sungai Kehidupan. Siswa yang hadir 24 orang. Pada pertemuan ini guru menjelaskan penerapan model pembelajaran kooperatif Jigsaw. Kemudian guru membagi siswa dalam lima kelompok asal yaitu masing-masing kelompok terdiri dari 4-5 orang siswa. Guru menjelaskan bahwa dengan penerapan model pembelajaran kooperatif Jigsaw diharapkan siswa lebih termotivasi dalam proses pembelajaran sehingga hasil belajar lebih meningkat.

Pengamatan dilakukan pada saat proses pembelajaran sedang berlangsung. Hasil pengamatan pada siklus I pertemuan 1 dapat diperoleh data bahwa dalam pertemuan 1 belum menerapkan model 
pembelajaran kooperatif Jigsaw sehingga siswa lebih banyak diam dalam proses pembelajaran. Berdasarkan hasil observasi tersebut dapat di simpulkan bahwa motivasi belajar siswa yang sangat rendah. Hal ini terlihat dari partisipasi siswa yang sangat rendah. Kemudian peneliti melakukan refleksi dengan tujuan mengetahui aspek yang akan diperbaiki pada pembelajaran selanjutnya. Pada pertmuan 1, yang harus diperbaiki adalah penggunaan model pembelajaran yang dapat meningkatkan motivasi belajar siswa. Salah satunya adalah model pembelajaran kooperatif Jigsaw. Selanjutnya penelti menyusunkan pelaksaan pembelajaran untuk pertemuan selanjutnya dengan tujuan meningkatkan motivasi belajar siswa sehingga hasilnya akan meningkat pula.

Hasil pengamatan, motivasi belajar siswa pada siklus I berkisar 70\%-76\% dengan persentasi tertinggi adalah adanya penghargaan dalam belajar pendidikan jasmani olahraga dan kesehatan. Bahwa jumlah siswa yang mencapai kriteria ketuntasan minimal (KKM) adalah 17 siswa $(70,83 \%)$ sedangkan yang belum mencapai ketuntasan adalah 7 siswa $(29,17 \%)$. Nilai rata-rata yang diperoleh siswa setelah penerapan model pembelajaran kooperatif Jigsaw pada siklus I adalah 76,67. Dengan demikian setelah di terapkannya tindakan hasil belajar siswa mengalami kenaikan sebesar 2.58 dari yang sebelum tindakan rata-ratanya adalah 68,25 menjadi 70,83 pada siklus I.

Berdasarkan hasil analisis dan refleksi pada siklus I melalui penerapan model pembelajaran kooperaitf Jigsaw, tindakan yang dilakukan dikatakan berhasil akan tetapi belum mencapai hasil yang maksimal. Pada motivasi belajar siswa memang mengalami peningkatan akan tetapi nilai rata-rata motivasi belajar belum mencapai target yang telah ditentukan yaitu 75\%. Sedangkan hasil belajar siswa nilai rata-rata kelas telah mencapai KKM namun persentasi jumlah siswa yang lulus masih kurang dari 75\%. Untuk itu perlu dilaksanakan siklus II sebagai langkah perbaikan proses pembelajaran pada siklus II. Pelaksanaan Tindakan.

Hasil motivasi belajar siswa siklus II, berdasarkan observasi menggunakan alat bantu angket. Presentasi motivasi belajar siswa siklus II berdasarkan angket dapat dilihat rata-rata besarnya motivasi belajar siswa pada siklus I berkisar antara 75,29\%$82,73 \%$ dengan prosentase rata rata $78,64 \%$. Pada siklus ini hanya satu indikator saja yang telah mencapai target yang ingin dicapai yaitu kesungguhan belajar siswa dengan prosentase $82,73 \%$. Dapat dilihat bahwa jumlah siswa yang mencapai kriteria ketuntasan minimal (KKM) adalah 21 siswa $(87,50 \%)$ sedangkan yang belum mencapai ketuntasan adalah 3 siswa (12,50\%). Nilai rata-rata yang diperoleh siswa setelah 
penerapan model pembelajaran kooperatif Jigsaw pada siklus II adalah 88,33. Dari data tersebut menunjukkan bahwa persentasi ketuntasan hasil belajar siswa telah melebihi indikator yang ingin dicapai yaitu $75 \%$.

Berikut ini diagram peningkatan prosentase rata-rata motivasi belajar siswa dalam penerapan model pembelajaran kooperatif tipe Jigsaw pada Pra Siklus, Siklus I dan Siklus II:

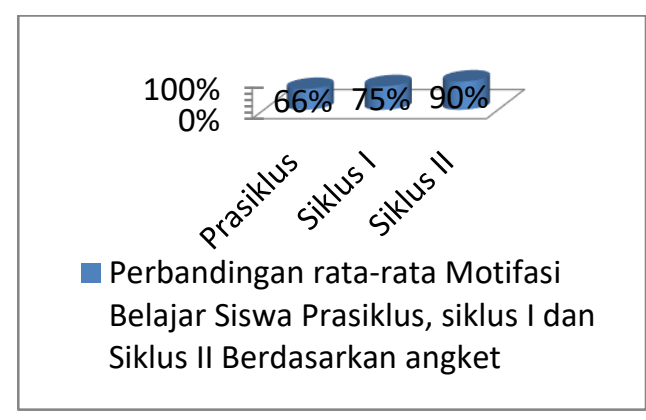

Berdasarkan diagram tersebut, dapat diketahui bahwa penerapan model pembelajaran kooperatif Jigsaw dapat meningkatkan motivasi belajar siswa. Hal tersebut terbukti dengan adanya peningkatan prosentase sebesar $7 \%$ dari $66 \%$ pada pra siklus menjadi $73 \%$ pada siklus I. Selanjutnya dari siklus I ke siklus II mengalami peningkatan sebesar $17 \%$ yaitu dari $73 \%$ pada siklus I menjadi $90 \%$ pada siklus II.

Hasil belajar, pada siklus I maupun siklus II hasil belajar siswa mengalami peningkatan yang cukup baik setelah diterapkannya model pembelajaran kooperatif Jigsaw. Berikut ini perbandingan perolehan nilai hasil belajar siswa pada pra siklus, siklus I dan siklus II di uraikan dalam tabel sebagai berikut:

Tabel 4.15 Perbandingan Nilai Hasil Belajar Siswa pada Pra Siklus, Siklus I dan Siklus II

\begin{tabular}{|c|c|c|c|c|}
\hline No & Nama & $\begin{array}{c}\text { Nilai } \\
\text { Pra } \\
\text { Siklus }\end{array}$ & $\left|\begin{array}{c}\text { Nilai } \\
\text { Siklus } \\
\text { I }\end{array}\right|$ & $\begin{array}{c}\text { Nilai } \\
\text { Siklus } \\
\text { II }\end{array}$ \\
\hline 1 & Agustina & 60 & 90 & 100 \\
\hline 2 & Celsy O & 73 & 80 & 100 \\
\hline 3 & Cristian & 80 & 90 & 90 \\
\hline 4 & Drwi S & 53 & 70 & 80 \\
\hline 5 & Febiy & 73 & 80 & 90 \\
\hline 6 & Fitri Y & 73 & 80 & 100 \\
\hline 7 & F.S.N & 67 & 80 & 100 \\
\hline 8 & Harun & 80 & 80 & 100 \\
\hline 9 & Juan J.T & 73 & 80 & 80 \\
\hline 10 & Kenneth & 73 & 90 & 90 \\
\hline 11 & Margaret & 67 & 80 & 90 \\
\hline 12 & Melisa & 67 & 70 & 80 \\
\hline 13 & Michele & 53 & 90 & 100 \\
\hline 14 & Norleti & 73 & 80 & 80 \\
\hline 15 & Oki S & 67 & 60 & 70 \\
\hline 16 & Putri V & 73 & 70 & 80 \\
\hline 17 & Sarafina & 73 & 80 & 100 \\
\hline 18 & Sisilia V & 60 & 60 & 70 \\
\hline 19 & Y C.B. & 60 & 50 & 80 \\
\hline 20 & Y.R & 60 & 80 & 90 \\
\hline 21 & Rasti P & 53 & 80 & 90 \\
\hline 22 & Gabriel & 87 & 80 & 100 \\
\hline 23 & H.W & 80 & 80 & 90 \\
\hline 24 & F.M.A & 60 & 60 & 70 \\
\hline & $\begin{array}{l}\text { lai Rata- } \\
\text { ta kelas }\end{array}$ & 68,25 & 76,67 & 88,33 \\
\hline
\end{tabular}


Untuk mengetahui peningkatan hasil belajar siswa, maka dapat digunakan nilai rata-rata kelas sebagai instrumen. Berikut ini perbandingan perolehan hasil belajar siswa pada pra siklus, siklus I dan siklus II dapat digambarkan dalam bentuk diagram sebagai berikut:

Gambar 4.9 Perbandingan Rata-rata Hasil Belajar Siswa Pra Siklus,

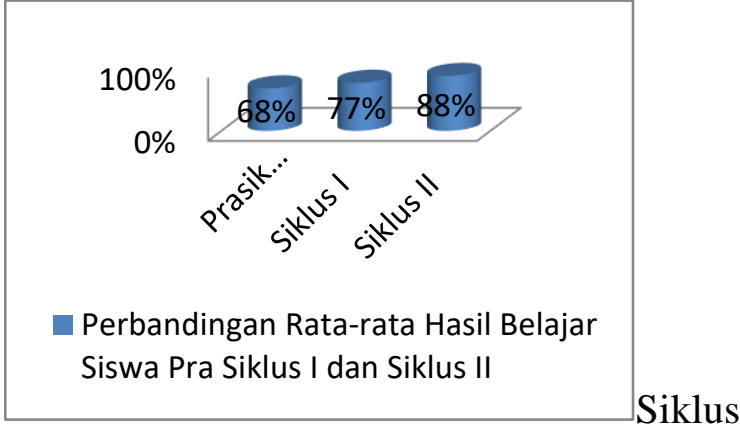

I da Siklus II (Sumber: data primer yang diolah, 2019).

Adapun perbandingan persentasi ketuntasan hasil belajar siswa dalam penerapan model pembelajaran kooperatif Jigsaw pada pra siklus, siklus I dan siklus II disajikan pula dalam bentuk gambar sebagai berikut:

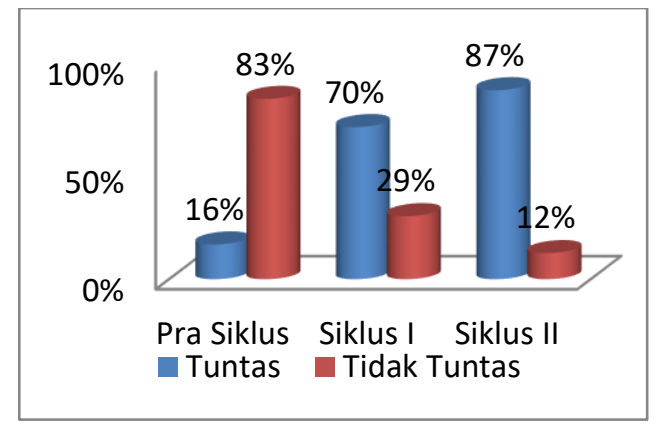

Gambar 4.10 Perbandingan persentasi ketuntasan hasil belajar siswa pra siklus, siklus I dan siklus II (Sumber: data primer yang diolah, 2019).

Berdasarkan tabel 4.10 dapat diketahui bahwa setelah diterapkan model pembelajaran kooperatif Jigsaw berdampak positif terhadap peningkatan hasil belajar siswa pada mata pelajaran Pendidikan Jasmani Olahraga dan Kesehatan. Hal tersebut nampak dengan adanya peningkatan nilai rata-rata dan peningkatan persentasi ketuntasan hasil belajar siswa setelah dilaksankan tindakan.

\section{PENUTUP}

\section{Kesimpulan}

Simpulan dari penelitian "Penerapan Model Pembelajaran Melalui Kooperatif Jigsaw Untuk Meningkatkan Motivasi Belajar. Berdasarkan hasil analisis penelitian tindakan dari siklus I sampai siklus II maka dapat disimpulkan bahwa terdapat peningkatan motivasi dan hasil belajar Pendidikan Jasmani Olahraga dan Kesehatan setelah diterapkannya model pembelajaran kooperatif Jigsaw pada siswa kelas V Sekolah Dasar Sungai Kehidupan Tahun Pelajaran 2019. Adapun penjelasannya sebagai berikut: Motivasi belajar Pendidikan Jasmani Olahraga dan Kesehatan siswa kelas V Sekolah Dasar Sungai Kehidupan berdasarkan: (1) Perhitungan angket pada siklus I ke siklus II mengalami kenaikan sebesar $17 \%$ yaitu dari motivasi belajar siswa pada siklus I sebesar $73 \%$ mengalami peningkatan pada siklus II menjadi 90\%. (2) Hasil belajar siswa mengalami peningkatan dari nilai rata-rata siswa pra siklus, yaitu 68,25 meningkat 8,42 pada siklus I sebesar 
76,67 mengalami kenaikan hasil belajar pada siklus II sebesar 11,66 dengan nilai rata-rata siswa mencapai 88,33. Ada beberapa saran yang dapat dipergunakan sebagai bahan pertimbangan antara lain: Guru diharapkan dapat mengembangkan model dan metode pembelajaran yang dapat mendorong motivasi belajar Sosiologi siswa serta dapat mempermudah siswa dalam memahami materi pelajaran, dan guru hendaknya perlu menambah wawasannya tentang metode-metode pembelajaran yang inovatif agar proses pembelajaran lebih menarik dan siswa tidak merasa bosan dalam mengikuti kegiatan belaj mengajar di kelas, serta guru hendaknya dapat memanfaatkan sarana dan prasarana yang sudah disediakan oleh sekolah sebagai alat bantu dalam pengembangan media pembelajaran.

Bagi Siswa, Dengan adanya penerapan model pembelajaran kooperatif Jigsaw sebaiknya dimanfaatkan dengan baik oleh siswa untuk bekerja sama dalam satu kelompok untuk memecahkan masalah dan saling mengajari satu sama lain. Siswa hendaknya lebih meningkatkan kemampuan untuk berdiskusi maupun bersosialisasi dengan siswa lain dan saling membantu terhadap siswa lain.

Bagi Sekolah, sebaiknya ada sosialisasi model-model pembelajaran yang lebih efektif kepada guru-guru agar mereka dapat menerapkannya di dalam kelas sehingga pembelajaran menjadi tidak monoton, serta pihak sekolah hendaknya semakin meningkatkan fasilitas-fasilitas sehingga dapat mendukung proses pembelajaran.

\section{DAFTAR PUSTAKA}

Aronson, E., Baney, N., Sikes, J., Stephan, C., \& Snapp, M., (1978). E History of the Jigsaw. [Online]. Tersedia: http:www.jigsaw.org/history.htm. diakses 30 juli 2019

Gulo, W. 2002. Metode Penelitian. Jakarta: PT. Grasindo

Kurt Lewin, (2009:146), Metodologi Penelitian pendekatan praktis dalam penelitian. Jogyakarta:penerbit andi.

Nurulhayati (2009:197), Manejemen Kurikulum. Jakarta: PT RajaGrafindo Persada. 